\title{
PENGARUH HARGA, KUALITAS PRODUK DAN KUALITAS PELAYANAN TERHADAP KEPUTUSAN PEMBELIAN PADA RUMAH MAKAN AYAM PENYET CABE IJO KOTA LANGSA
}

\author{
Yulina Astuti ${ }^{1}$, Faisal Hamdani ${ }^{2}$, Muhammad Zulkarnain ${ }^{3}$
}

\begin{abstract}
This study aims to determine the effect of price, product quality and service quality on purchasing decisions at the Chicken Penyet Cabe Ijo Restaurant in Langsa City, either partially or simultaneously. The population in this study are consumers who make purchasing decisions at the Chicken Penyet Cabe Ijo Restaurant in Langsa City. The research sample was taken 10\% of the total population of the study so that the number of samples in this study amounted to 55 respondents. The sampling technique used non probability sampling using purposive sampling. Methods of data analysis using multiple linear regression equations with the help of SPSS software performed t test, F test and coefficient of determination test. To prove the hypothesis partially, the t test was carried out for each variable, where the price variable was obtained $t$ sig $<5 \%$ so that it could be stated that the price had a significant effect on purchasing decisions, the product quality variable was obtained $t$ sig $<5 \%$ so that it could be stated that the product quality had an effect. significant on purchasing decisions, and the variable quality of service obtained $t$ sig $<5 \%$ so it can be stated that service quality has a significant effect on purchasing decisions. and to prove the hypothesis simultaneously an F test is carried out, so that F Sig $<5 \%$ is obtained so that it can be stated that the price, product quality and service quality simultaneously affect the purchasing decision at the Chicken Penyet Chili Ijo Restaurant, Langsa City. The test of the coefficient of determination $(R 2)$ is $52.8 \%$. Price, product quality and service quality affect purchasing decisions at the Chicken Penyet Chili Ijo Restaurant, Langsa City.
\end{abstract}

Keywords: Price, Product Quality, Service Quality and Purchase Decision

\footnotetext{
${ }^{1}$ Sekolah Tinggi Ilmu Manajemen Pase Langsa, yulina.astuti.ya@gmail.com

${ }^{2}$ Sekolah Tinggi IImu Manajemen Pase Langsa, hamdanifaisal434@gmail.com

${ }^{3}$ Sekolah Tinggi Ilmu Manajemen Pase Langsa, m.zulkarnain28@gmail.com
} 


\section{PENDAHULUAN}

Pertumbuhan bisnis makanan dan minuman yang sangat cepat mendorong perusahaan untuk bersaing dalam setiap aktivitas bidang pemasaran. Dalam menghadapi persaingan yang ketat didunia usaha diperlukan adanya strategi yang tepat untuk menghadapi para pesaing. Salah satu kegiatan usaha makanan dan minuman adalah rumah makan, dimana berbagai makanan dan minuman yang disajikan harus mencerminkan perbedaan dengan para pesaing. Sehingga para pelaku usaha dituntut agar dapat menarik konsumen untuk melakukan keputusan pembelian terhadap produk yang ditawarkan.

Keputusan pembelian merupakan suatu proses penyelesaian masalah yang terdiri dari menganalisa atau pengenalan kebutuhan dan keinginan, pencarian informasi, penilaian sumber-sumber, seleksi terhadap alternative pembelian dan perilaku setelah pembelian. keputusan membeli oleh seorang konsumen terhadap suatu produk diawali dengan kesadaran pembeli akan adanya kebutuhan(Anindya, 2020). Terdapat beberapa hal yang mempengaruhi keputusan pembelian seorang konsumen diantaranya harga produk yang ditawarkan.

Menurut Anindya, (2020) harga adalah nominal yang bisa menjadi suatu barang atau jasa menjadi bernilai, yang bisa menjadi pendapatan ataupun bisa menjadi suatu biaya. Selain harga konsumen membeli sebuah produk karena kualitas produknya, kualitas produk merupakan penentu konsumen melakukan pembelian artinya jika pelaku usaha menjaga kualitas produk maka konsumen tidak akan lari ke produk lain dan akan tetap mengkonsumsi produk tersebut. Selain harga dan kualitas produk, kualitas pelayanan juga mempengaruhi keputusan pembelian konsumen. Pelayanan yang diberikan dapat menarik minat konsumen untuk melakukan keputusan pembelian.

Salah satu bisnis yang menyediakan makanan dan minuman yang ada di Kota Langsa adalah Rumah Makan Ayam Penyet Cabe Ijo, café yang menyediakan berbagai macam jenis makanan dan minuman guna memenuhi kebutuhan konsumen. Dalam melakukan kegiatan bisnisnya Rumah Makan Ayam Penyet Ijo perlu memperhatikan faktor-faktor yang mempengaruhi keputusan pembelian produknya, seperti harga yang ditetapkan apakah harga tersebut kompetitif dibandingkan dengan produk pesaing, produk yang tawarkan apakah kualitas produk yang dimiliki lebih baik dari pada produk pesaing, dan kualitas pelayanan yang ditawarkan kepada konsumen apakah lebih baik atau tidak. Hal-hal seperti ini perlu diperhatikan agar Rumah Makan Ayam Penyet Cabe Ijo dapat menarik konsumen untuk membeli produknya.

Telah banyak dilakukan penelitian yang berkaitan dengan harga, kualitas produk dan kualitas pelayanan terhadap keputusan pembelian, dimana beberapa hasil penelitian menyatakan bahwa Harga, Kualitas Produk dan Kualitas Pelayanan berpengaruh terhadap Keputusan pembelian(Wijaya, 2017;Hutagalung \& Waluyo, 2020; Anindya, 2020). Namun ada beberapa penelitian yang menyatakan bahwa harga berpengaruh 
negative dan tidak signifikan terhadap keputusan pembelian hal ini mengartikan bahwa harga bukan faktor penentu dari keputusan pembelian (Destarini \& Prambudi, 2020). Sementara penelitian yang dilakukan oleh Daiyah et al., (2018) menyatakan bahwa harga dan kualitas pelayanan secara parsial berpengaruh positif dan signifikan terhadap keputusan pembelian, namun kualitas produk secara parsial berpengaruh positif tetapi tidak signifikan terhadap keputusan pembelian.

Berdasarkan permasalahan inkonsistesi penelitian yang terjadi ,maka penelitian ini mencoba untuk menkaji apakah harga, kualitas produk dan kualitas pelayanan berpengaruh terhadap keputusan pembelian pada Rumah Makan Ayam Penyet Cabe Ijo Di Kota Langsa.

\section{Keputusan Pembelian}

Sebuah keputusan melibatkan pilihan antara dua atau lebih tindakan, keputusan selalu membutuhkan pilihan antara perilaku. Keputusan pembelian adalah suatu keputusan yang diambil oleh seorang calon pembeli atau tidak (Kotler \& Armstrong, 2016). Sementara Peter \& Olson, (2010) keputusan pembelian adalah proses integrasi dimana pengetahuan digabungkan untuk mengevaluasi dua atau lebih perilaku alternative dan memilih satu. Dimana proses integrasi dipresentasikan secara kognitif sebagai niat perilaku (Behavioral Intention /BI). Proses pengambilan keputusan pembelian merupakan proses pemilihan alternative sebagai pemecahan masalah (Siregar et al., 2017).

Keputusan pembelian adalah proses pengambilan keputusan yang dilakukan dengan terlebih dahulu melakukan evaluasi, pencarian informasi atas produk/jasa, dimana proses evaluasi berkaitan langsung dengan upaya untuk mendapatkan sebuah produk/jasa, mengkonsumsi produk/jasa, serta tindakan lain yang dilakukan sebelum mendapatkan dan mengkonsumsi/ menggunakan produk/jasa tersebut (Khuong \&Duyen dalam Sijabat, 2020). Keputusan pembelian merupakan kegiatan pemecahan masalah yang dilakukan individu dalam pemilihan alternative perilaku yang sesuai dari dua alternative perilaku atau lebih dan dianggap sebagai tindakan yang paling tepat dalam membeli dengan terlebih dahulu melalui tahapan proses pengambilan keputusan (Firmans yah, 2019).

Anoraga dalam Siregar et al., (2017) konsumen dalam melakukan keputusan pembelian dihadapkan pada 4 (empat) peran sebagai berikut :

a. Pengambil inisiatif (initiator) yaitu seseorang yang pandangannya atau sarannya diperhitungkan dalam pengambilan keputusan.

b. Orang yang mempengaruhi (influencer), yaitu seseorang yang memutuskan sebagai besar keputusan membeli seperti apakah jadi membeli, apa yang dibeli, bagaimana membelinya, atau dimana membelinya.

c. Pembeli (buyer) yaitu seseorang yang melakukan pembelian yang sebenarnya. 
IHTIYATH Jurnal Manajemen Keuangan Syariah

Vol. 5 No. 1, September 2021

d. Pemakai (user), yaitu seseorang yang mengkonsumsi atau menggunakan barang atau asa yang dibeli.

Kotler \& Keller, (2016) proses keputusan pembelian terdiri dari lima tahapan; pengenalan kebutuhan, pencarian informasi, evaluasi alternative, keputusan pembelian, dan perilaku pascapembelian.

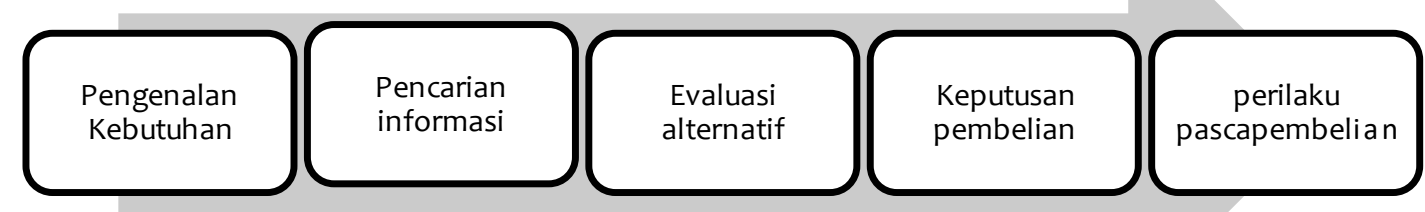

\section{Gambar 1}

\section{Tahapan Proses Keputusan Pembelian}

Kotler \& Keller, (2016) menyatakan ada enam (6) indikator keputusan pembelian yang dilakukan oleh konsumen yaitu ;

a. Pilihan produk

b. Pilihan merek

c. Pilihan penyalur

d. Waktu pembelian

e. Jumlah pembelian

f. Metode pembayaran

\section{Harga}

Harga merupakan suatu yang diserahkan dalam pertukaran untuk mendapatkan suatu barang dan jasa (Kotler, Philip. \& Armstrong, 2008;Sitorus, 2020; Wijaya, 2017). Didalam keputusan pembelian, pengetahuan konsumen mengenai harga sebuah produk membentuk persepsi tentang produk tertentu. Harga merupakan nilai moneter yang bersedia diberikan oleh konsumen sebagai imbalan atas produk atau layanan tertentu (Sijabat, 2020). Sementara Armstrong et.el dalam Sitorus, (2020) menjelaskan bahwa harga adalah sejumlah uang yang dibebankan atas suatu produk atau jasa, atau jumlah dari nilai yang ditukarkan konsumen atas manfaat-manfaat kerena memiliki atau menggunakan produk atau jasa tersebut.

Ada empat indicator harga (Sitorus, 2020) yaitu;

a. Keterjangkauan harga

b. Kesesuaian harga dengan kualitas produk 
c. Daya saing Harga

d. Kesesuaian harga dengan manfaat.

\section{Kualitas Produk}

Kualitas produk adalah salah satu penentu proses penentu proses keputusan pembelian konsumen, apabila kualitas produk sesuai harapan konsumen akan melakukan keputusan pembelian. kesesuaian penggunaan atau sejauhmana suatu produk berhasil memenuhi tujuan konsumen ( Beverly dalam Sugiarto \& Jumady, 2019). Kualitas Produk adalah kemampuan suatu produk untuk melaksanakan fungsinya meliputi, daya tahan keandalan, ketepatan kemudahan operasi dan operasi dan perbaikan, serta atribut bernilai lainnya (Daga, 2017). Sementara Armstrong et al., (2017) menyatakan kualitas produk adalah karakteristik produk atau layanan yang didasarkan peda kemampuannya untuk memenuhi kebutuhan konsumen.

Kotler dalam Daga,(2017) mengatakan bahwa dimensi dari kualitas produk dibagi menjadi 2 bagian yaitu;

a. Level (performance quality) kemampuan suatu produk untuk menampilkan fungsifungsinya. Performance quality dapat diukur melalui :

1) Kenyamanan (comfortable) kemampuan produk memberikan, kemudahan dan kenyamanan bagi penggunanya.

2) Ketahanan (durability), umur produk atau seberapa lama produk tersebut bertahan sampai akhirnya harus diganti

3) Model atau desain (design) produk mempunyai model dan nilai kesesuaian dengan selera konsumen

4) Kualitas bahan (material) produk terbuat dari bahan yang berkualitas dan mendukung fungsi produk.

b. Consistency (conformance quality) yaitu konsistensi atau stabil dalam memberikan kualitas yang diharapkan konsumen, artinya kualitas tersebut mempunyai standar yang memang tercermin dalam produk. Conformance quality dijelakan dalam

1) Bebas dari cacat dan kegagalan (freedom fro defects), bebas dari kesalahankesalahan dalam proses produksinya.

2) Konsistensi (concistency) secara konsisten mempertahankan kinerja produk untuk diberikan kepada pelanggan, sesuai dengan yang diharapkan.

\section{Kualitas Pelayanan}

Kualitas adalah totalitas fitur dan karakteristik suatu produk atau layanan yang menghasilkan kemampuannya untuk memenuhi kebutuhan yang dinyatakan (Kotler \& Keller, 2016). Pelayanan tidak dapat disentuh atau diukur dengan cara apapun sebelum dibeli oleh konsumen (Kenyon \& Sen, 2015), sementara pelayanan menurut Kotler \& Keller,(2016) tindakan atau kinerja apapun yang dapat ditawarkan satu pihak kepada 
pihak lain yang pada dasarnya tidak berwujud dan tidak menghasilkan kepemilikan apapun. Jadi kualitas pelayanan adalah perbandingan layanan yang dirasakan dengan pelayanan yang diharapkan (Kotler \& Keller, 2016).

Model kualitas pelayanan (Kotler \& Keller, 2016) memberikan gambaran bagaimana penghantaran kualitas pelayanan yang baik terhadap konsumen.

a. Kesenjangan antara harapan konsumen dan persepsi manajemen.

b. Kesenjangan antara persepsi manajemen dan spesifikasi kualitas layanan

c. Kesenjangan antara spesifikasi kualitas layanan dan pemberian layanan.

d. Kesenjangan antara pemberian layanan dan komunikasi eskternal

e. Kesenjangan antara layanan yang dirasakan dan yang diharapkan.

Berdasarkan model kualitas pelayanan tersebut, ada lima determinan kualitas pelayanan yang dapat digunakan sebagai alat pengukuran (Kotler \& Keller, 2016; Kenyon \& Sen, 2015) :

a. Reliabilitas, kemampuan untuk melakukan layanan yang dijanjikan dengan andal dan akurat

b. Responsiveness, kesediaan untuk membantu pelanggan dan memberikan layanan yang cepat

c. Assurance, pengetahuan dan kesopanan karyawan dan kemampuan mereka untuk menyampaikan kepercayaan dan keyakinan.

d. Empati, pemberian perhatian individual terhadap pelanggan

Benda berwujud, munculnya fasilitas fisik, peralatan, staf dan materi komunikasi..

\section{METODE PENELITIAN}

Metode penelitian ini adalah penelitian deskriptif yang merupakan suatu prosedur pemecahan masalah yang diselidiki dengan menggambarkan atau melukiskan keadaan pada masa sekarang. Populasi dalam penelitian ini adalah konsumen Rumah Makan Ayam Penyet Cabe Ijo dengan jumlah perhitungan rata-rata dalam 1 bulan mencapai 550 orang. Dari jumlah populasi ini kemudian diambil sampel dengan teknik purposive sampling yaitu pengambilan sampel dengan pertimbangan tertentu, yang menjadi pertimbangan dalam dalam pengambilan sampel ini adalah tingkat usia 20 tahun ke atas dan melakukan pembelian di Rumah Makan Ayam Penyet Cabe Ijo. Sampel penelitian diambil $10 \%$ dari jumlah keseluruhan populasi 550 orang konsumen sehingga sampel diperoleh sebanyak 55 orang responden.

Jenis data dalam penelitian ini yaitu data kualitatif dan kuantitatif. Data kualitatif pada penelitian ini berupa teori-teori yang berkenaan dengan variabel-variabel penelitian. Data kuantitatif berupa tanggapan responden yang diukur dengan skala likert. Sedangkan sumber data dalam penelitian ini merupakan data primer yang 
diperoleh dengan cara melakukan wawancara, observasi dan pemberian kuesioner pada objek penelitian yaitu konsumen yang melakukan keputusan pembelian pada Rumah Makan Ayam Penyet Cabe Ijo.

Penelitian ini menggunakan analisis regresi linier berganda dengan model persamaan sebagai berikut :

$$
Y=a+b_{1} X_{1}+b_{2} X_{2}+b_{3} X 3
$$

Dimana :

$$
\begin{array}{ll}
\mathrm{Y} & =\text { Keputusan Pembelian } \\
\mathrm{X}_{1} & =\text { Harga } \\
\mathrm{X}_{2} & =\text { Kualitas Produk } \\
\mathrm{X}_{3} & =\text { Kualitas Pelayanan } \\
\mathrm{b}_{1}, \mathrm{~b}_{2}, \mathrm{~b}_{3} & =\text { Koefisien regresi. }
\end{array}
$$

\section{HASIL DAN PEMBAHASAN}

Berdasarkan hasil penyebaran kuesioner kepada 55 orang responden dan dilakukan pengolahan data dengan menggunakan bantuan software SPSS, maka diketahui usia responden yang melakukan keputusan pembelian pada Rumah Makan Ayam Cabe Ijo dapat dilihat pada Tabel 1.

Tabel 1

Usia Responden

\begin{tabular}{ccc}
\hline Usia (Tahun) & Frekuensi & Persentase $(\%)$ \\
\hline $\mathbf{2 0 - 2 9}$ & 17 & 30,9 \\
$\mathbf{3 0}-\mathbf{3 9}$ & 22 & 40,0 \\
$\mathbf{4 0}-\mathbf{4 9}$ & 13 & 23,6 \\
$\mathbf{5 0}-\mathbf{5 9}$ & 3 & 5,5 \\
Jumlah & 55 & 100 \\
\hline
\end{tabular}

Sumber : Hasil Penelitian, 2021

Berdasarkan Tabel 1 menjelaskan bahwa keputusan pembelian pada Rumah Makan Ayam Penyet Cabe Ijo banyak dilakukan oleh responden yang berusia 30 -39 Tahun sebanyak 40,0 \%, Kemudian usia 20-29 tahun sebanyak 30,9 \%, dan usia 40-49 tahun sebanyak 23,6\%, serta yang paling sedikit melakukan keputusan pembelian berusia 50-59 tahun sebanyak 5,5\%. 
IHTIYATH Jurnal Manajemen Keuangan Syariah

Vol. 5 No. 1, September 2021

Berdasarkan jenis kelamin yang banyak melakukan keputusan pembelian pada Rumah Makan Ayam Penyet Cabe Ijo adalah Laki-Laki sebanyak 72,2\% dan perempuan sebanyak 27,3\%. hal ini dapat terlihat pada Tabel 2.

Tabel 2

Jenis Kelamin

\begin{tabular}{ccc}
\hline Jenis Kelamin & Frekuensi & Persentase (\%) \\
\hline Laki - Laki & 40 & 72,7 \\
Perempuan & 15 & 27,3 \\
Jumlah & 55 & 100 \\
\hline
\end{tabular}

Sumber : Hasil Penelitian, 2021

Berdasarkan Tingkat Pendidikan keputusan Pembelian Pada Rumah Makan Ayam Penyet Cabe Ijo banyak dilakukan oleh tingkat pendidikan Sekolah Menengah Atas (SMA) sebanyak 60,0\%, kemudian tingkat pendidikan sarjana sebanyak 29,1\%, dan tingkat pendidikan diploma sebanyak 10,9\%. Hal ini dijelaskan ada Tabel 3.

Tabel 3

Tingkat Pendidikan Responden

\begin{tabular}{ccc}
\hline Tingkat Pendidikan & Frekuensi & Persentase (\%) \\
\hline SMA & 33 & 60,0 \\
Diploma & 6 & 10,9 \\
Sarjana & 16 & 29,1 \\
Jumlah & 55 & 100 \\
\hline
\end{tabular}

Sumber : Hasil Penelitian, 2021

Berdasarkan Pekerjaan responden yang melakukan keputusan pembelian pada Rumah Makan Ayam Penyet Cabe Ijo banyak dilakukan oleh pegawai swasta sebanyak 41,8\%, wiraswasta sebanyak 30,9\%, Pegawai Negeri sebanyak 16,4\% dan Ibu Rumah Tangga Sebanyak 10,4\%. Penjelasan ini dapat dilihat pada Tabel 4.

Tabel 4

Pekerjaan Responden

\begin{tabular}{ccc}
\hline Pekerjaan & Frekuensi & Persentase (\%) \\
\hline Pegawai Negeri & 9 & 16,4 \\
Pegawai Swasta & 23 & 41,8 \\
\hline
\end{tabular}


Wiras wasta

Ibu Rumah Tangga

Jumlah
17

6

55
30,9

10,9

100

Sumber : Hasil Penelitian, 2021

Berdasarkan Tingkat Pendapatan responden yang melakukan keputusan pembelian pada Rumah Makan Ayam Penyet Cabe ijo, responden yang memiliki tingkat pendapatan Rp 2.000.000-Rp 2.500.000 yang banyak melakukan keputusan pembelian sebanyak 34,5\%. Kemudian responden yang memiliki tingkat pendapatan < Rp 2.000 .000 sebanyak 29,1\%. Dan responden yang memiliki tingkat pendapatan > Rp 2.500.000-Rp 3.000.000 sebanyak 25,5\%, sementara responden yang memiliki pendapatan > Rp 3.000.000-Rp 4.000.000 hanya 10,9\%.

Tabel 5

Tingkat Pendapatan

\begin{tabular}{lcc}
\hline Tingkat Pendapatan & Frekuensi & Persentase (\%) \\
\hline$\leq$ Rp 2.000.000 & 16 & 29,1 \\
$>$ Rp 2.000.000-Rp 2.500.000 & 19 & 34,5 \\
$>$ Rp 2.500.000-Rp 3.000.000 & 14 & 25,5 \\
$>$ Rp 3.000.000-Rp 4.000.000 & 6 & 10,9 \\
Jumlah & 55 & 100 \\
\hline
\end{tabular}

Sumber : Hasil Penelitian, 2021

Berdasarkan hasil penelitian persamaan regresi linier berganda diperoleh persamaan $\mathrm{Y}=0,401+0,362 \mathrm{X}_{1}+0,228 \mathrm{X} 2+0,136 \mathrm{X} 3$. Hal ini menjelaskan bahwa koefisien konstanta $=0,401$. Hal ini menunjukkan bahwa jika nilai dari seluruh variabel bebas yang terdiri dari Harga, Kualitas Produk dan Pelayanan bernilai 0 maka Keputusan Pembelian bernilai 0,401. Sementara untuk nilai koefisien harga diperoleh sebesar 0,362, hal ini menjelaskan bahwa jika variabel harga mengalami kenaikan sebesar $1 \%$ maka hal tersebut akan diikuti oleh kenaikan Keputusan Pembelian sebesar 0,362. Nilai koefisien variabel kualitas Produk sebesar 0,228 hasil ini menunjukkan bahwa jika variabel kualitas produk mengalami kenaikan sebesar 1\% maka hal tersebut akan diikuti oleh kenaikan keputusan pembelian sebesar 0,228. Sama juga dengan variabel kualitas pelayanan, nilai koefisien kualitas pelayanan sebesar 0,136 hasil ini menunjukkan bahwa jika variabel kualitas pelayanan mengalami kenaikan sebesar $1 \%$ maka hal tersebut akan diikuti oleh kenaikan keputusan pembelian sebesar 0,136. Dari hasil nilai koefisien ketiga variabel menunjukkan bahwa nilai bernilai positif artinya 
IHTIYATH Jurnal Manajemen Keuangan Syariah

Vol. 5 No. 1, September 2021

terdapat pengaruh antara variabel harga, Kualitas Produk dan kualitas Pelayanan dengan variabel Keputusan Pembelian.

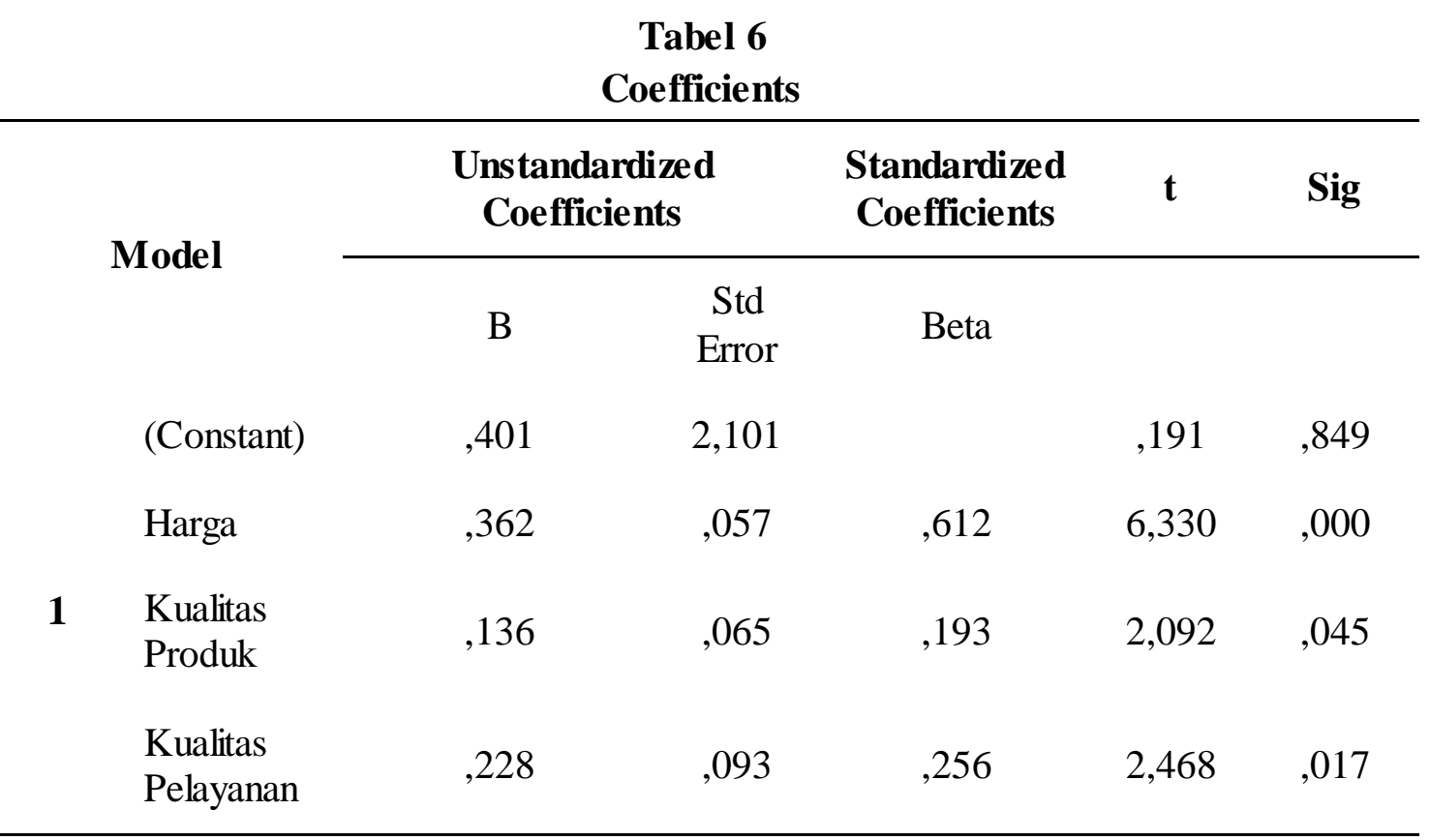

Sumber : Hasil Penelitian, 2021

Dari hasil pengolahan data kemudian dilakukan uji t untuk membuktikan hipotesis secara parsial dan diperoleh nilai $\mathrm{t}$ sig variabel harga $<5 \%(0,000<0,05)$ sehingga dapat dinyatakan bahwa harga berpengaruh signifikan terhadap keputusan pembelian pada Rumah Makan Ayam Penyet Cabe Ijo Kota Langsa dan hipotesis dapat diterima. Hal ini sejalan dengan penelitian yang dilakukan oleh Anindya,( 2020) dengan judul penelitian pengaruh Harga, Kualitas Produk, dan Kualitas Pelayanan Terhadap Keputusan Pembelian Pada Sami Remen. Hasil penelitian menyatakan bahwa harga berpengaruh positif dan signifikan terhadap keputusan pembelian. penelitian ini menolak hasil penelitian yang dilakukan Destarini \& Prambudi, (2020) dengan judul Pengaruh Produk dan harga terhadap Keputusan pembelian Pada Konsumen 212 Mart Condet Batu Ampar. Hasil penelitian menyatakan harga memiliki pengaruh negative dan tidak signifikan terhadap keputusan pembelian hal ini berarti harga bukan faktor penentu dari keputusan pembelian. Berdasarkan hal tersebut hasil penelitian ini dapat diterima bahwa harga berpengaruh terhadap keputusan pembelian pada Rumah Makan Ayam Penyet Cabe Ijo Kota Langsa dengan nilai $t$ hitung $>t_{\text {tabel }}(6,330>2,007)$ dengan nilai signifikansi kurang dari $0,05(0,000<0,05)$ maka hipotesis diterima.

Variabel kualitas produk diperoleh nilai $\mathrm{t}$ sig $<5 \%(0,045<0,05)$ sehingga dapat dinyatakan bahwa kualitas produk berpengaruh signifikan terhadap keputusan pembelian pada Rumah Makan Ayam Penyet Cabe Ijo Kota Langsa dan hipotesis dapat diterima. Hal ini sependapatan dengan penelitian yang dilakukan oleh Anindya,( 2020) dan penelitian yang dilakukan oleh Hutagalung \& Waluyo, (2020) dengan judul Pengaruh Kualitas Produk , Kualitas pelayanan dan Harga terhadap Keputusan Pembelian (Studi Kasus Pada Kopi Benteng 2 Banyumanik) dengan hasil penelitian 
terdapat pengaruh antara kualitas produk terhadap keputusan pembelian. sehingga hasil penelitian ini dapat diterima bahwa kualitas produk berpengaruh terhadap keputusan pembelian pada Rumah Makan Ayam penyet Cabe Ijo Kota Langsa dengan nilai thitung $_{\text {> }}$ $\mathrm{t}_{\text {tabel }}(2,092>2,007)$ dengan nilai signifikansi kurang dari 0,05 maka hipotesis diterima.

Sementara variabel kualitas pelayanan diperoleh nilai t sig $<5 \%(0,017<0,05)$ sehingga dapat dinyatakan bahwa kualitas pelayanan berpengaruh signifikan terhadap keputusan pembelian pada Rumah Makan Ayam Penyet Cabe Ijo Kota Langsa dan hipotesis dapat diterima. Penelitian ini mendukung hasil penelitian yang dilakukan oleh (Anindya, 2020 ; Hutagalung \& Waluyo, 2020) menyatakan kualitas pelayanan berpengaruh terhadap keputusan pembelian. hasil penelitian ini menyatakan bahwa kualitas pelayanan berpengaruh terhadap keputusan pembelian pada Rumah Makan Ayam Penyet Cabe Ijo dengan nilai $t_{\text {hitung }}>t_{\text {tabel }}(2,468>2,007)$ dengan nilai signifikasi kurang dari $0,05(0,017<0,05)$ sehingga hipotesis penelitian diterima.

Untuk menguji hipotesis secara simultan dilakukan uji $\mathrm{F}$ diperoleh hasil seperti yang ditampilkan pada Tabel 2 berikut :

Tabel 7

Anova

\begin{tabular}{llccccc}
\hline Model & $\begin{array}{c}\text { Sum of } \\
\text { Square }\end{array}$ & df & $\begin{array}{c}\text { Mean } \\
\text { Square }\end{array}$ & F & Sig \\
\hline \multirow{2}{*}{$\mathbf{1}$} & Regression & 89,580 & 3 & 29,860 & 18,996 &, 000 \\
& Residual & 80,165 & 51 & 1,572 & & \\
& Total & 169,745 & 54 & & & \\
\hline
\end{tabular}

Sumber : Hasil Penelitian,2021

Berdasarkan Pengaruh harga, kualitas produk dan kualitas pelayanan terhadap Keputusan Pembelian yang dilakukan secara simultan (bersama-sama) diperoleh hasil pengujian pada Tabel 7 menjelaskan bahwa nilai $F_{\text {hitung }}>F_{\text {tabel }}(18,996>2,79)$ dengan nilai signifikansi kurang dari $0,05(0,000<0,05)$. Hal ini berarti bahwa harga, kualitas produk dan kualitas pelayanan berpengaruh secara simultan dan signifikan terhadap keputusan pembelian pada Rumah Makan Ayam Penyet cabe Ijo Kota Langsa.

Selanjutnya untuk mengukur seberapa jauh kemampuan model dalam menerangkan variasi variabel digunakan hasil pengolahan data yang ditunjukkan pada Tabel 8 berikut : 
IHTIYATH Jurnal Manajemen Keuangan Syariah

Vol. 5 No. 1, September 2021

Tabel 8

Model Summary

\begin{tabular}{ccccc}
\hline Model & R & R Square & $\begin{array}{c}\text { Adjusted R } \\
\text { Square }\end{array}$ & $\begin{array}{c}\text { Std Error of the } \\
\text { Estimate }\end{array}$ \\
\hline $\mathbf{1}$ &, 726 &, 528 &, 500 & 1,25374 \\
\hline
\end{tabular}

Sumber : Hasil Penelitian,2021

Berdasarkan hasil pengujian pada Tabel 8 diketahui bahwa nilai R sebesar 0,726. Hal ini menunjukkan bahwa hubungan antara variabel independen dengan variabel dependen kuat. Sedangkan nilai $\mathrm{R}$ Square $\left(\mathrm{R}^{2}\right)$ sebesar 0,528 atau 52,8\% artinya sebesar $52,8 \%$ variabel harga, kualitas produk dan kualitas pelayanan mempengaruhi keputusan pembelian pada Rumah Makan Ayam Penyet Cabe Ijo Kota Langsa dan sisanya sebesar $47,2 \%$ dipengaruhi oleh variabel lain yang tidak masuk dalam penelitian ini.

\section{KESIMPULAN}

Berdasarkan hasil penelitian dan pembahasan dalam penelitian ini, maka penulis mengemukakan kesimpulan penelitian ini sebagai berikut:

a. Dari hasil persamaan ditunjukkan bahwa harga, kualitas produk dan kualitas produk berpengaruh positif terhadap keputusan pembelian pada Rumah Makan Ayam Penyet Cabe ijo Kota Langsa.

b. Hasil pengujian hipotesis secara parsial terhadap variabel harga diperoleh bahwa hipotesis diterima dengan nilai $\mathrm{t}$ sig $<0,05$. Dan pengujian hipotesis secara parsial terhadap variabel kualitas produk diperoleh bahwa hipotesis diterima dengan nilai $\mathrm{t}$ sig $<0,05$ dan pengujian hipotesis variabel kualitas pelayanan secara parsial diperoleh bahwa hipotesis diterima dengan nilai $\mathrm{t}$ sig $<0,05$. Sehingga dapat disimpulkan secara parsial harga , kualitas produk dan kualitas pelayanan berpengaruh terhadap keputusan pembelian pada Rumah Makan Ayam Penyet Cabe Ijo Kota Langsa.

c. Hasil pengujian hipotesis secara simultan dengan uji $\mathrm{F}$ diperoleh $\mathrm{F}$ sig $<0,05$ sehingga dapat disimpulkan harga, kualitas produk dan kualitas pelayanan secara bersama-sama (simultan) berpengaruh signifikan terhadap Keputusan Pembelian Pada Rumah Makan Ayam Penyet Cabe ijo Kota Langsa.

Dan hasil uji koefisien determinasi $\left(\mathrm{R}^{2}\right)$ menunjukkan bahwa harga, kualitas produk dan kualitas pelayanan mempengaruhi keputuan pembelian pada Rumah Makan Ayam Penyet Cabe Ijo Kota Langsa sebesar 52,8\% dan sisanya 47,2\% dipengaruhi oleh variabel lain yang tidak termasuk dalam penelitian ini. 


\section{DAFTAR PUSTAKA}

Anindya, R. (2020). Pengaruh Harga, Kualitas Produk, Kualitas Pelayanan, Terhadap Keputusan Pembelian Pada "SAMI REMEN." IQTISHADequity, 2(2).

Armstrong, G., Kotler, P., Trifts, V., Buchwitz, L. A., \& Gaudet, D. (2017). Marketing An Introduction (Canadian 6). Pearson Canada Inc.

Daga, R. (2017). Citra, Kualitas produk, Dan Kepuasan Pelanggan (Issue May 2017). Global Research And Consulting Institute.

Daiyah, F., Mansur, M., \& Hufron, M. (2018). Pengaruh Ptresepsi Harga, Kualitas Produk Dan Kualitas Pelayanan Terhadap Keputusan Pembelian Produk Three Second Secara Online. Jurnal Riset Manajemen, 7(3), 95-107.

Destarini, F., \& Prambudi, B. (2020). Pengaruh Produk Dan Harga Terhadap Keputusan Pembelian Pada Konsumen 212 Mart Condet Batu Ampar. JURNAL EKOBIS:EKONOMI,BISNIS \&MANAJEMEN, 10(1), 58-66.

Firmansyah, M. A. (2019). Buku Pemasaran Produk dan Merek. CV. Penerbit Qiara Media.

Hutagalung, Y. M., \& Waluyo, H. D. (2020). Pengaruh Kualitas Produk, Kualitas Pelayanan Dan Harga Terhadap Keputusan Pembelian (Studi Kasus Kopi Benteng 2 Banyumaik). Jurnal Administrasi Bisnis, IX(III), 209-215.

Kenyon, G. N., \& Sen, K. C. (2015). The perception of quality: Mapping product and service quality to consumer perceptions. In Springer-Verlag London.

Kotler, Philip. \& Armstrong, G. (2008). Prinsip-Prinsip Pemasaran, Jilid 1. In Manajemen Pemasaran (Vol. 7, p. 1835).

Kotler, P., \& Armstrong, G. (2016). Principles of Marketing (16th ed.). Pearson Education.

Kotler, P., \& Keller, K. L. (2016). Marketing Management. In Pearson Education Inc (15th ed.). Pearson Education Inc.

Peter, J. paul, \& Olson, J. C. (2010). Consumer Behavior \& Marketing Strategy (9th ed.). McGraw-Hill.

Sijabat, R. (2020a). Analisis Peran Mediasi Harga Terhadap Asosiasi Country Of Origin, Perceived Quality, dan Brand Image Terhadap Keputusan Pembelian. JURNAL MANAJEMEN, 17(1), 57-80.

Sijabat, R. (2020b). Analisis Peran Mediasi Harga Terhadap Asosiasi Country Of Origin, Perceived Quality, Dan Brand Image Terhadap Keputusan Pembelian. JURNAL MANAJEMEN, 17(1), 57-80.

Siregar, B. G., Nasution, H. F., \& Aisyah, S. (2017). Pengaruh Kualitas Produk, Harga, Promosi Dan Atribut Produk Terhadap Keputusan Pembelian Pasta Gigi Pepsodent Pada Mahasiswa Jurusan Ekonomi Syariah Fakultas Ekonomi Dan Bisnis Islam Iain Padangsidimpuan. Al-Masharif: Jurnal Ilmu Ekonomi Dan Keislaman, 5(2), 58. https://doi.org/10.24952/masharif.v5i2.1438 
IHTIYATH Jurnal Manajemen Keuangan Syariah

Vol. 5 No. 1, September 2021

Sitorus, S. A. (2020). Pengaruh Harga, Rasa, Lokasi Dan Iklan Terhadap Keputusan Pembelian Ayam Penyet Di Kota Medan. HIRARKI Jurnal Ilmiah Manajemen Dan Bisnis, 2(2), 131-142. https//doi.org/Http://doi.org/10.30606/hjimb

Sugiarto, S., \& Jumady, E. (2019). Kualitas Produk dan Layanan Purna Jual Terhadap Keputusan Pembelian Sepeda Motor Yamaha Pada PT Suraco Jaya Abadi Motor. JUMBO (Jurnal Manajemen, Bisnis Dan Organisasi), 3(3), 152-161.

Wijaya, C. V. (2017). Pengaruh Harga, Kualitas Pelayanan Dan Kualitas Produk Terhadap Kepuasan Konsumen Depot Madiun Masakan Khas Bu Rudy. Agora, $5(1)$, $1-8$. scholar.google.co.id/scholar?hl=en\&as_sdt=0\%2C5\&q=bu+rudy\&btnG=\#d=gs _qabs\&u=\%23p\%3DjSbeuTSQd6YJ 